\title{
The Efficiency of Hepatitis C Virus Core Antigen Test in the Diagnosis of Hepatitis C Infection
}

\author{
Hepatit C Enfeksiyonunun Tanısında Hepatit C Virüsü Kor Antijen Testinin Etkinliği
}

\author{
Mehmet Emin DEMIRCILI1, Mehmet ÖZDEMIR2, Bahadır FEYZIOĞLU2, Bülent BAYSAL2 \\ 1/stanbul University Istanbul Faculty of Medicine, Department of Medical Microbiology, Istanbul, Turkey \\ 2Necmettin Erbakan University Meram Faculty of Medicine, Department of Medical Microbiology, Konya, Turkey
}

\begin{abstract}
Objective: It was aimed to investigate diagnostic value of hepatitis $\mathrm{C}$ virus $(\mathrm{HCV})$ core antigen test in patients with positive or negative anti-HCV assay by comparing with HCV ribonucleic acid (RNA) assay. Materials and Methods: Serum samples obtained from 189 patients who were admitted to Necmettin Erbakan University Meram Faculty of Medicine between December 2010 and February 2012, and HCV RNA assay were carried out for various reasons. Two $\mathrm{mL}$ of samples were stored under suitable conditions and anti$\mathrm{HCV}, \mathrm{HCV}$ core antigen and strip immunoblot assay [Commercial INNO LIA ${ }^{\mathrm{TM}}$ HCV Score (Innogenetics NV in Ghent, Belgium)] were performed. Genotyping was performed in the amplicons of the samples with positive HCV RNA test.

Results: The diagnostic sensitivity specificity, negative predictive value and positive predictive value of HCV core antigen test were $96.2 \%, 100 \%, 97.3 \%$, and $100 \%$, respectively. Sixty-five serum samples were genotyped and their distribution were detected: Fiftynine samples were genotype 1b, 2-genotype 1a/1b, 1-genotype 3a, 1-genotype 4, 1-genotype 2a/2c, and 1 was genotype $1 \mathrm{a}$.

Conclusion: It was concluded that HCV core antigen assay is highly specific, sensitive, reliable, reproducible, and easy to perform. It may be applied as a supplemental and confirmatory test in anti-HCV assays in the diagnosis of HCV.

Keywords: Hepatitis C virus, core antigen, hepatitis C virus ribonucleic acid, strip immunoblot assay
\end{abstract}

\section{ÖZ}

Amaç: Hepatit C virüsü (HCV) kor antijen testinin tanı değerinin anti$\mathrm{HCV}$ testi pozitif veya negatif olan hastalarda HCV ribonükleik asit (RNA) ile kıyaslanarak araştııımasıdır.

Gereç ve Yöntemler: Necmettin Erbakan Üniversitesi Üniversitesi Meram Tıp Fakültesi'ne Aralık 2010- Şubat 2012 tarihleri arasında başvuran ve çeşitli nedenlerle HCV RNA testi çalışlan 189 hastadan elde edilen serum örnekleri bu çalışmaya dahil edildi. Iki $\mathrm{mL}$ serum örneği uygun koşullar altında saklandı ve anti HCV, HCV kor antijen ve strip immünblot testi [Ticari INNO LIATM HCV Score testi (Innogenetics NV in Ghent, Belçika)] testleri çalışıldı. HCV RNA pozitif olan örneklere genotipleme yapıldı

Bulgular: Çalışmamızda HCV kor antijen testinin sensitivite, spesifite; negatif prediktif değer ve pozitif prediktif değerleri sırayla $\% 96,2, \% 100$, \%97,3 ve \%100 olarak tespit edildi. Genotipleme yapılan 65 örneğin $59^{\prime}$ u genotip 1b, 2'si genotip $1 a / 1 b$, 1 'i genotip $3 a$, 1 'i genotip 4, 1'i genotip 2a/2c ve 1'i genotip 1a olarak tespit edildi. Sonuç: HCV kor antijen testi sensitivitesi ve spesifitesi yüksek, kolay uygulanabilir, güvenilir bir testtir. Bu test HCV enfeksiyonunun tanısında anti-HCV test sonuçlarının konfirmasyon ve tamamlayıcı testi olarak kullanılabilir.

Anahtar Kelimeler: Hepatit C Virüsü, kor antijen, hepatit C virüsü ribonükleik asit, strip immünblot testi 


\section{Introduction}

Hepatitis C virus (HCV) is classified within the genus Hepacivirus in the Flaviviridae family. It is a single-stranded RNA virus with positive polarity $(1,2)$. There are approximately 200 million individuals infected with HCV throughout the world. Moreover, $\mathrm{HCV}$ is considered as the most important reason for liver diseases in both developed and developing countries (3). HCV prevalence varies greatly in geographic distribution depending on the level of development of the country. High prevalence is found in Africa and Asia, whereas the ratio is lower in industrialized countries, such as Australia, North America, and Northern and Western Europe (4). It has been divided into six main genotypes and more than 80 different subtypes according to the nucleotide sequences of $\mathrm{HCV}$ (2). There is a close relationship between the genotypes and subtypes of HCV and pathogenesis and epidemiology of the disease $(5,6)$.

Nowadays, anti-HCV assays, which detect antibodies against $\mathrm{HCV}$ and used as a screening test to detect HCV in blood and blood products, are performed in order to prevent transmission of $\mathrm{HCV}$. Although screening tests are highly effective in reducing the risk of hepatitis $\mathrm{C}$, they can give false-positive test results in some individuals without any clinical or laboratory findings related to $\mathrm{HCV}$ infection $(7,8)$. However, strip immunoblot assay $(S I A)$ is used as a supplementary test for positive anti-HCV assay results. This test has some disadvantages, such as difficulty of performing, high cost and a high percentage of indeterminate results (9). Although molecular methods are currently the most reliable method for determining $\mathrm{HCV}$ infection, they are time consuming and expensive and require high-technical equipment (10).

$\mathrm{HCV}$ core antigen is a protein which has 191 amino acids and its molecular weight is $21 \mathrm{kDa}$ (11). HCV core antigen can be detected approximately 1-2 days after the emergence of HCV RNA and before the formation of anti-HCV antibodies in serum (12).

The aim of the study was to evaluate the diagnostic efficiency of $\mathrm{HCV}$ core antigen assay among anti-HCV-seropositive and seronegative individuals by comparing with HCV RNA assay.

\section{Materials and Methods}

This investigation was designed as a cross-sectional study. The study sample was collected from sera in which HCV RNA testing was performed for various reasons in our laboratory. One hundred eighty nine sera were obtained between December 2010 and February 2012. One hundred nine samples were taken from the HCV RNA-positive sera. As a control group, 80 samples were collected from HCV RNA-negative sera. The control group patients were admitted to the hospital for reasons not related to hepatitis infection.

The clinical research Ethics Committee of Meram Faculty of Medicine approved the study.

Anti-HCV assay was studied using commercial Architect ${ }^{\circledR}$ i2000SR chemiluminescence immunoassay (CIA) system (Abbott laboratories, diagnostics division, abbott Park, IL, USA) chemiluminescent microparticle immunoassay technology.

SIA was performed using Commercial INNO LIATM HCV Score (Innogenetics NV in Ghent, Belgium).

HCV core antigen assay was carried out using Architect ${ }^{\circledR}$ i2000SR CIA system (Abbott laboratories, diagnostics division, and Abbott Park, IL, USA). This test is a new generation HCV core antigen assay. The test was performed following the manufacturer's instructions. $110 \mu \mathrm{l}$ of each sample was used in the study and test period was 36-40 min. for each sample. The cut off value was 3.00 $\mathrm{fmol} /$ iter $(0.06 \mathrm{pg} / \mathrm{mL})$ according to manufacturer's instructions. Thus, $<3.00 \mathrm{fmol} /$ liter was considered as non-reactive and $\geq 3.00$ $\mathrm{fmol} /$ liter was considered as reactive. The test results that were between $\geq 3.00 \mathrm{fmol} /$ liter and $<10.00 \mathrm{fmol} /$ liter were retested. If both assays were nonreactive, test result was considered as nonreactive in terms of HCV core antigen. If one or both of the repeated tests were $\geq 3.00 \mathrm{fmol} /$ liter, the test was considered as reactive (13).

Commercial COBAS ${ }^{\circledR}$ AmpliPrep/COBASv TaqMan ${ }^{\circledR}$ HCV Test (Roche Molecular Systems, USA), a nucleic acid amplification test, was applied in HCV RNA quantification. The assay features are low limit of detections $(15 \mathrm{IU} / \mathrm{mL})$ and quantification of HCV RNA, all genotypes, with a linear range of 43 to $69.000 .000 \mathrm{IU} / \mathrm{mL}$.

The samples were prepared using COBAS ${ }^{\circledR}$ AmpliPrep device, and amplification and detection was performed automatically by using COBAS ${ }^{\circledR}$ TaqMan ${ }^{\circledR} 48$ analyzer device (Roche Molecular Systems, USA).

HCV genotyping was performed by a commercial Ampliquality HCV-TS (AB ANALITICA, Padova, Italy).

\section{Statistical Analysis}

Statistical analysis was carried out with SPSS version 16.0 (SPSS Inc, USA, IL). p value of less than 0.05 was considered statistically significant. The sensitivity, specificity, positive predictive value (PPV) and negative predictive value (NPV) were calculated for statistical analysis of the data. Spearman's correlation coefficient was used to assess the linear relationship between HCV core antigen and HCV RNA concentrations. Pearson's correlation coefficient was used to assess the linear relationship between HCV core antigen concentrations and viral load values after log transformation.

\section{Results}

The study included 189 patients (80 male and 109 female). The mean age of the patients was $51.37 \pm 18.4$ years.

Anti-HCV assay revealed that 148 serum samples were reactive and 41 were non-reactive.

Two samples were detected to be anti-HCV positive, HCV core antigen positive, SIA positive and, HCV RNA negative. When the HCV RNA assay was repeated with new serum samples 3 weeks later, positive HCV RNA results were obtained.

When the HCV core antigen test results of 8 samples with the values of $\geq 3.00 \mathrm{fmol} /$ liter and $<10.00 \mathrm{fmol} /$ liter were retested, 6 were evaluated as non-reactive and 2 were evaluated as reactive. According to the results of SIA (Commercial INNO LIATM HCV Score), 78 samples were positive, 103 were negative, and 8 samples were found to be indeterminate.

Study results are given in Table 1.

The HCV core Ag results are given according to HCV viral load in Table 2.

HCV RNA levels of three samples detected to be HCV RNApositive and $\mathrm{HCV}$ core antigen-negative were $1.5 \times 10^{1} \mathrm{IU} / \mathrm{mL}, 2.7$ $\times 10^{1} \mathrm{IU} / \mathrm{mL}$ and $2.57 \times 10^{3} \mathrm{IU} / \mathrm{mL}$.

Spearman's correlation coefficient was calculated as 0.874 , and a linear association was found between HCV RNA and HCV core antigen $(p<0.01)$. 
The correlation between the levels of HCV RNA and core antigen was significant $(r=0.840, p<0.01)$.

The relationship between concentrations of HCV RNA and HCV core antigen is shown in Figure 1.

The results of the HCV core antigen test were compared to HCV RNA. Sensitivity, specificity, NPV, PPV, and accuracy of HCV core antigen test were $96.2 \%, 100 \%, 97.3 \%, 100 \%$, and $98.4 \%$, respectively.

Only 65 serum samples were genotyped. Their distribution were defined as follows: 59 were genotype 1b, 2 - genotype 1a / 1 b, 1 - genotype 3a, 1 - genotype 4, 1 - genotype 2a/2c and 1 was genotype $1 \mathrm{a}$.

\section{Discussion}

$\mathrm{ClA}$ and enzyme immunoassay (EIA), the most widely used methods in the diagnosis of HCV infection, have been used as a screening test (2). An important disadvantage of anti-HCV assay is that the rate of false-positive results is high especially at low anti-HCV value $(8,14,15)$. According to the CDC guidelines, if anti-HCV results are low S/Co, a supplemental test is required (16).

Another disadvantage of anti-HCV assay is false-negative results. The reason for these cases are severe immunosuppression, hemodialysis, AIDS and agammaglobulinemia $(17,18,19)$. In this

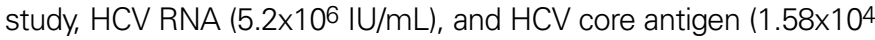
$\mathrm{fmol} / \mathrm{L}$ ) were positive in serum of a chronic liver disease patient with a negative anti-HCV assay (0.12). Moreover, SIA (Commercial INNO LIATM HCV Score) result of this sample was evaluated as negative. It was accepted as immunosuppression.

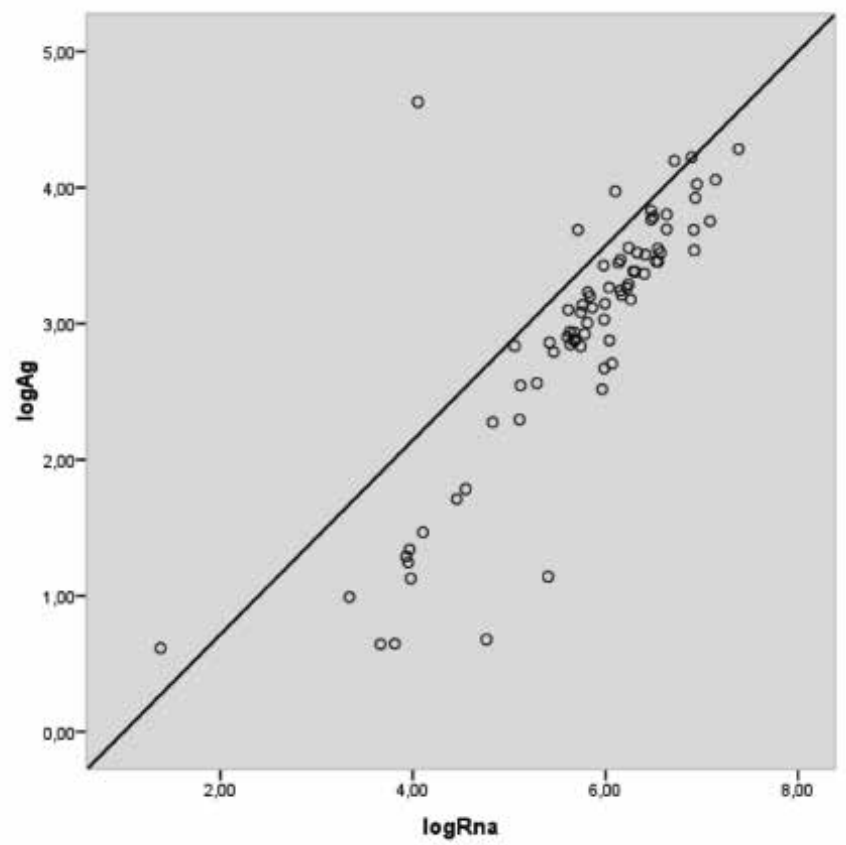

Figure 1. Correlation between hepatitis $C$ virus ribonucleic acid (HCV RNA) and core Ag levels. Pearson's correlation coefficient showed a high correlation between the levels of HCV RNA and core antigen $(r=0.840, p<0.01)$
In recent years, confirmation of $\mathrm{HCV}$ replication has been shown to be possible by detecting and measuring HCV core antigen. While detection limit of the first generation HCV core antigen tests has been $1.5 \mathrm{pg} / \mathrm{mL}$, that of the second generation test has been $0.06 \mathrm{pg} / \mathrm{mL}$ (3 fmol/L) $(12,18,20)$.

HCV RNA levels have correlated with serum HCV core antigen. However, when the level of serum HCV RNA has decreased, number of false-negative results of HCV core antigen assay have increased $(21,22,23,24)$. In this study, three serum samples with a low level of HCV RNA $\left(1.5 \times 10^{1} \mathrm{IU} / \mathrm{mL}, 2.7 \times 10^{1} \mathrm{IU} / \mathrm{mL}\right.$ and 2.57 $\times 10^{3} \mathrm{IU} / \mathrm{mL}$ ) were detected with positive HCV RNA and negative $\mathrm{HCV}$ core antigen. The correlation between HCV RNA and HCV core antigen was significant $(r=0.874, p<0.01)$.

In this study, two samples were detected to be anti-HCVpositive, HCV core antigen-positive, SIA-positive and, HCV RNAnegative. When the HCV RNA assay was repeated with new serum samples 3 weeks later, we obtained positive HCV RNA results. These results may appear in non-viremic HCV RNA period. In the presence of such a situation, HCV RNA should be repeated with new samples after several weeks $(25,26)$

In our study, SIA (Commercial INNO LIATM HCV Score) was detected indeterminately and HCV RNA was detected negative in eight serum samples with positive anti-HCV assay. Anti-HCV S/ Co results were $\leq 4.39$ in the sera with indeterminate SIA results (Commercial INNO LIATM HCV Score). These results suggest that results of positive anti-HCV and indeterminate SIA should be confirmed with HCV RNA. Nevertheless, the results of these sera samples with $\mathrm{HCV}$ core antigen assay were also non-reactive.

In this study, HCV core antigen sensitivity, specificity, PPV and NPV were found to be $96.2 \%, 100 \%, 100 \%$, and $97.3 \%$, respectively. These results were consistent with that of similar previous studies. Daniel et al. (27) found $85.3 \%$ sensitivity and $95.8 \%$ specificity, Miedouge et al. (23) found $100 \%$ sensitivity and $99.2 \%$ specificity,

Table 1. The results of SIA, HCV core antigen and anti-HCV assay

\begin{tabular}{|l|l|l|l|l|}
\hline Test result & HCV RNA & Anti-HCV & HCV core Ag & SIA \\
\hline Positive & 80 & 148 & 77 & 78 \\
\hline Negative & 109 & 41 & 112 & 103 \\
\hline Indeterminate & - & - & - & 8 \\
\hline \multicolumn{5}{|l}{ HCV: Hepatitis C virus, SIA: Strip immunoblot assay } \\
\hline
\end{tabular}

Table 2. Hepatitis $C$ virus ribonucleic acid core ag results according to hepatitis $C$ virus ribonucleic viral load

\begin{tabular}{|l|l|l|l|}
\hline \multirow{2}{*}{} & & \multicolumn{3}{|l|}{ HCV core Ag } \\
\cline { 3 - 4 } & & Negative & Positive \\
\hline \multirow{3}{*}{ HCV RNA } & Negative & 109 & 0 \\
\cline { 2 - 4 } & Positive & 3 & 77 \\
\hline \multirow{3}{*}{$\begin{array}{l}\text { Viral load } \\
\text { (IU/mL) }\end{array}$} & $15-20.000$ & 3 & 10 \\
\cline { 2 - 4 } & $20.000-100.000$ & 0 & 4 \\
\cline { 2 - 4 } & $100.000-500.000$ & 0 & 14 \\
\cline { 2 - 4 } & $500.000-800.000$ & 0 & 9 \\
\cline { 2 - 4 } & $>800.000$ & 0 & 40 \\
\hline
\end{tabular}

HCV RNA: Hepatitis $\mathrm{C}$ virus ribonucleic acid, $\mathrm{HCV}$ : Hepatitis $\mathrm{C}$ virus ribonucleic 
Kesli et al. (25) found 96.3\% sensitivity and 100\% specificity, Yuksel et al. (28) found $94.3 \%$ sensitivity and $97.9 \%$ specificity, Ergünay et al. (29) found $75.8 \%$ sensitivity and $95.1 \%$ specificity, and Arıdoğan et al. (30) found $86.5 \%$ sensitivity and $100 \%$ specificity.

PPV and NPV values in other studies were as follows: Daniel et al. (27) found 96.4\% PPV and 83.1\% NPV, Kesli et al. (25) found 100\% PPV and 89.7\% NPV, Yuksel et al. (28) found 99.1\% PPV and 87\% NPV, and Arıdoğan et al. (30) found 100\% PPV and 59.4\% NPV.

In this study, HCV core antigen sensitivity rate (96.2\%) was higher than the results of Daniel et al. (27) (85.3\%), Ergünay et al. (28) (75.8\%), and Arıdoğan et al. (30) (86.5\%), and was very close to the results of Kesli et al. (25) (96.3\%), Yuksel et al. (28) (94.3\%), and was lower than that of Miedouge et al. (23) (100\%). In our study and other studies, specificity and PPV of HCV core antigen test were found to be quite high. This result suggests that positive core antigen test results are an important parameter in predicting the presence of the disease.

In conclusion, HCV antigen assay is highly specific, sensitive, reliable, reproducible, and easy to perform. It may be useful as a complementary and confirmatory test in anti-HCV assays.

\section{Ethics}

Ethics Committee Approval: The study were approved by Necmettin Erbakan University Meram Faculty of Medicine Ethics Committee, Informed Consent: Verbal consent was obtained.

Peer-review: External and Internal peer-reviewed.

\section{Authorship Contributions}

Surgical and Medical Practices: Mehmet Emin Demircili, Mehmet Özdemir, Bahadır Feyzioğlu, Bülent Baysal, Concept: Mehmet Emin Demircili, Mehmet Özdemir, Bahadır Feyzioğlu, Bülent Baysal, Design: Mehmet Emin Demircili, Mehmet Özdemir, Bahadır Feyzioğlu, Bülent Baysal, Data Collection or Processing: Mehmet Emin Demircili, Mehmet Özdemir, Analysis or Interpretation: Mehmet Emin Demircili, Mehmet Özdemir, Bahadır Feyzioğlu, Bülent Baysal, Literature Search: Mehmet Emin Demircili, Writing: Mehmet Emin Demircili

Conflict of Interest: No conflict of interest was declared by the authors.

Financial Disclosure: This study was supported by Scientific Research Projects.

Demircili ME, Özdemir M, Feyzioğlu B, Baysal B. The Efficiency of Hepatitis $C$ virus Core Antigen Test in the Diagnosis of Hepatitis C Infection. Viral Hepatitis J 2016;22:18-22.

\section{References}

1. Suzuki T. Morphogenesis of infectious hepatitis $C$ virus particles. Front Microbiol. 2012;3:38.

2. Scott JD, Gretch DR. Hepatitis $C$ and G viruses. In: Murray PR, Baron EJ, Jorgensen JH, Landry ML, Pfaller MA (eds.), Manual of Clinical Microbiology. 9th ed. Ankara: Atlas Publishing; 2007; p. 1437-1452.

3. Alavian SM, Aalaei-Andabili SH. Lack of knowledge about hepatitis $\mathrm{C}$ infection rates among patients with inherited coagulation disorders in countries under the eastern mediterranean region office of WHO (EMRO): A Meta-Analysis. Hepat Mon. 2012;12:244-252.

4. Paraboni ML, Sbeghen MD, Wolff FH, Moreira LB. Risk factors for infection with different hepatitis $C$ virus genotypes in southern Brazil. Scientific World Journal. 2012;2012:946954.
5. Pawlotsky JM, Prescott $L$, Simmonds P, Pellet C, Laurent-Puig P, Labonne C, Darthuy F, Remire J, Duval J, Buffet C,Etienne JP, Dhumeaux D, Dussaix E. Serological determination of hepatitis $C$ virus genotype: comparison with a standardized genotyping assay. J Clin Microbiol. 1997;35:1734-1739.

6. Çelik C, Bakıcı MZ, Kaygusuz R, Ertürk R. The searching of HCV genotyping distributions in the region of Sivas. Viral Hepatitis Journal. 2010;16:106-110.

7. Gretch DR. Diagnostic tests for hepatitis C. Hepatology. 1997;26:43-47

8. Dufour DR, Talastas M, Fernandez MD, Harris B, Strader DB, Seeff LB. Low-positive anti-hepatitis C virus enzyme immunoassay results: an important predictor of low likelihood of hepatitis C infection. Clin Chem. 2003;49:479-486.

9. Kesli R, Ozdemir M, Kurtoglu MG, Baykan M, Baysal B. Evaluation and comparison of three different anti-hepatitis $C$ virus antibody tests based on chemiluminescence and enzyme-linked immunosorbent assay methods used in the diagnosis of hepatitis C infections in Turkey. J Int Med Res. 2009;37:1420-1429.

10. Daniel HD, Vivekanandan P, Raghuraman S, Sridharan G, Chandy GM, Abraham P. Significance of the hepatitis $\mathrm{C}$ virus (HCV) core antigen as an alternative plasma marker of active HCV infection. Indian J Med Microbiol. 2007;25:37-42.

11. Seme K, Poljak M, Babic DZ, Mocilnik T, Vince A. The role of core antigen detection in management of hepatitis $\mathrm{C}$ : a critical review. J Clin Virol. 2005;32:92-101.

12. Hosseini-Moghaddam SM, Iran-Pour E, Rotstein C, Husain S, Lilly L, Renner E, Mazzulli T. Hepatitis C core Ag and its clinical applicability: potential advantages and disadvantages for diagnosis and follow-up? Rev Med Virol. 2012;22:156-165.

13. Morota K, Fujinami R, Kinukawa H, Machida T, Ohno K, Saegusa $H$, Takeda K. A new sensitive and automated chemiluminescent microparticle immunoassay for quantitative determination of hepatitis $\mathrm{C}$ virus core antigen. J Virol Methods. 2009;157:8-14.

14. Acar A, Kemahli S, Altunay H, Kosan E, Oncul O, Gorenek L, Cavuslu S. HBV, HCV and HIV seroprevalence among blood donors in Istanbul, Turkey: how effective are the changes in the national blood transfusion policies? Braz J Infect Dis. 2010;14:41-46.

15. Tbakur V, Guptan RC, Arankale V, Sarin SK. Low specificity of the third generation ELISA for HCV detection in voluntary blood donors in India. EJIFCC. 2003;14.

16. Alter MJ, Kuhnert WL, Finelli L; Centersfor Disease Control and Prevention. Guidelines for laboratory testing and result reporting of antibody to hepatitis $\mathrm{C}$ virus. Centersfor Disease Control and Prevention. MMWR Recomm Rep. 2003;7;52:1-13.

17. Kesli R. An overview of the laboratory assay systems and reactives used in the diagnosis of hepatitis $C$ virus (HCV) infections.In Abuelzein $\mathrm{E}$ ed. Trends in Immunolabelled and Related Techniques.In Tech Publishing House, Rijeka, Croatio; 2012:339-350.

18. Mederacke I, Wedemeyer $\mathrm{H}$, Ciesek S, Steinmann E, Raupach R, Wursthorn K, Manns MP, Tillmann HL. Performance and clinical utility of a novel fully automated quantitative HCV-core antigen assay. J Clin Virol. 2009;46:210-215.

19. Chamie G, Bonacini M, Bangsberg DR, Stapleton JT, Hall C, Overton ET, Scherzer R, Tien PC. Factors associated with seronegative chronic hepatitis $\mathrm{C}$ virus infection in HIV infection. Clin Infect Dis. 2007;44:577-583.

20. Vermehren J, Susser S, Berger A, Perner D, Peiffer $\mathrm{KH}$ Allwinn R, Zeuzem S, Sarrazin C. Clinical utility of the Architect HCV Ag assay for early treatment monitoring in patients with chronic hepatitis $\mathrm{C}$ genotype 1 infection. J Clin Virol. 2012;55:17-22. 
21. Bouvier-Alias $M$, Patel $K$, Dahari $H$, Beaucourt $S$, Larderie $P$, Blatt L, Hezode C, Picchio G, Dhumeaux D, Neumann AU, McHutchison JG, Pawlotsky JM. Clinical utility of total HCV core antigen quantification: a new indirect marker of $\mathrm{HCV}$ replication. Hepatology. 2002;36:211-218.

22. Saito R, Yokota H, Takahashi E, Mashige F, Yoneyama A, Nakahara K, Okamura N. Performance of an automated system for quantitation of hepatitis C virus core antigen. J Virol Methods. 2003;112: 93-97.

23. Miedouge M, Saune K, Kamar N, Rieu M, Rostaing L, Izopet J. Analytical evaluation of $\mathrm{HCV}$ core antigen and interest for $\mathrm{HCV}$ screening in haemodialysis patients. J Clin Virol. 2010;48:1821.

24. Chevaliez S. Virological tools to diagnose and monitor hepatitis C virus infection. Clin Microbiol Infect. 2011;17:116-121.

25. Kesli R, Polat H, Terzi Y, Kurtoglu MG, Uyar Y. Comparison of a newly developed automated and quantitative hepatitis $C$ virus (HCV) core antigen test with the HCV RNA assay for clinical usefulness in confirming anti-HCV results. J Clin Microbiol. 2011;49:4089-4093.
26. Chevaliez S, Pawlotsky JM. Hepatitis C virüs serologic and virologic tests and clinical diagnosis of HCV-related liver disease. Int J Med Sci. 2006;3:35-40.

27. Daniel HD, Vivekanandan $P$, Raghuraman $S$, Sridharan G, Chandy $\mathrm{GM}$, Abraham P. Significance of the hepatitis $\mathrm{C}$ virus (HCV) core antigen as an alternative plasma marker of active HCV infection. Indian J Med Microbiol. 2007;25:37-42.

28. Yuksel P, Caliskan R, Ergin S, Aslan M, Celik DG, Saribas S, Ziver T, Yalciner A, Kocazeybek B. New approaches to in vitro diagnosis of hepatitis $\mathrm{C}$ infection a reason for post transfusion hepatitis: Diagnostic value of determination of hepatitis $C$ virus core antigen. Transfus Apher Sci. 2011;45:247-250.

29. Ergünay K, Sener B, Alp A, Karakaya J, Hasçelik G. Utility of a commercial quantitative hepatitis $C$ virus core antigen assay in a diagnostic laboratory setting. Diagn Microbiol Infect Dis. 2011;70:486-491.

30. Arıdoğan BC, Aynalı A, Kaya S, Onal S, Cetin ES. Comparison of HCV core antigen and anti-HCV with HCV RNA results. Afr Health Sci 2014;14:816-819. 